\title{
THE CHANGING CHARACTER OF PUBLIC SPACE IN AN EASTERN MEDITERRANEAN PORT CITY: FROM CUSTOMS SQUARE TO GRAND BAZAAR IN MERSİN Tolga ÜNLÜ*
}

Received: 01.11.2011; Final Text: 01.08.2012

Keywords: public space; character of place; Eastern Mediterranean port cities; Mersin; Customs Square.
* Department of City and Regional Planning, Mersin University , Mersin, TURKEY.

\section{INTRODUCTION}

Mersin is located in the Çukurova region, known as the Cilicia region in antiquity, which is one of the most fertile lands along the Mediterranean coast of Turkey. Its foundation dates to the first half of the nineteenth century when it was a mere village on the shore, after which "the Eastern Mediterranean emerged as an area of modernity from the 1830s onwards" (Fuhrmann and Kechriotis, 2009). Being a port city in the region, Mersin was affected by the modernisation reforms of the late Ottoman period, which resulted in "the evolution of the autarkic economy into a free market, and gave rise to prosperity in port cities" (Keyder et al., 1993; Sifneos, 2005). Consequently, a new hierarchical pattern of commercial relations began to emerge in the coastal zones rather than a pattern of relatively isolated urban centres (Costello, 1980). The economic world opened up to merchants through the utilisation of business organisations and networks that extended beyond the limits of national boundaries; and the Ottoman Empire offered merchants of different national, religious and ethnic backgrounds some measure of autonomy (Keyder, 2008).

As was the case with other cities in the Mediterranean during this period, Mersin took on economic, cultural and spatial characteristics common to many other port cities. On the one hand Mersin became a gateway between Anatolia and the outside world, as "a spatial expression of its core-periphery relations" (Keyder et al., 1993), connecting the agrarian periphery and the industrial core; while on the other, its spatial development took on an "archetypal image of density, urban complexity and social diversity" (Munoz, 2003). This all resulted in the development of a multi-cultural social pattern owing to the presence of Greek and Levantine merchants who were engaged in international commercial activities based on maritime trade, banking, importing, exporting and insurance. 
In this context, since its foundation during the first half of the nineteenth century until the first decades of the twentieth century Mersin had been a city of modernisation on the southern Mediterranean coast of Anatolia, and a distinctive port in the Eastern Mediterranean due to the growth of international relations with other Mediterranean port cities and the development of commercial activities. Customs Square, flanked by Customs House and Customs Pier, was at the very centre of not only the internal public space system of Mersin, but also its international relations, being at the forefront of social, economic and spatial life.

The rapid development, from the early Republican period until today, especially since the middle of the twentieth century, has transformed the city from a mercantile port of exchange into one of the most prominent port cities in the Eastern Mediterranean. Particularly during the last three decades, incremental urban interventions in the city centre and investments in large-scale housing projects and shopping centres in new development areas have resulted in a degradation of the city centre, and a retreat of the public into other parts of the city.

Customs Square was affected by the growing importance of private realms, however it was the construction of the modern port and the demolition of Customs Pier during the rapid development throughout the second half of the twentieth century that had a major effect on the character of Customs Square, which would come to be referred to as the "Grand Bazaar" in later decades. Customs Square lost its significance and meaning within urban life as people migrated to the private realm.

Taking Customs Square in Mersin as the core research area, this study questions the change in the qualitative characteristics of public space in relation to urban development and changes in social processes. Moreover it examines the effect of urban plans and projects to publicize and change its character. Thus, formation and transformation of public space stands at the very centre of the discussion. The focus will mainly on the dynamics and forces that affect the way Customs Square came into being and acquired its character, dealing with several questions. First, why and how did Customs Square evolve into a Grand Bazaar, and which forces and dynamics affected and directed such a transformation? Secondly, does the decline in use of Customs Square in recent decades when compared to the period when Mersin was a small town stem only from the migration of people from public places to private realms, or thirdly is it a problem of how to the design public spaces? The analysis of the transformation originated from the question of whether the change was actually only a revision of the name of the place, however this raises the question of whether substantial change was brought to the essence of the place that would eventually influence its character formation.

The study will focus firstly on discussion about public space in general and the urban square in particular in order to clarify the terms to be used in the paper and to develop a methodological framework. In the second part, the transformation of Customs Square into the Grand Bazaar is considered in relation to the urban development of the city as a whole.

\section{PUBLIC SPACE AND URBAN SQUARE}

Consideration of public space as a physical entity involves many aspects. Arguably, "public space" refers to all streets, squares and other rights of way, as well as open spaces and parks (Carmona et al., 2008), being areas 
to which everyone has physical and visual access and in which the greatest amount of human contact and interaction takes place (Tibbalds, 2001). It has been suggested that it offers the potential for interaction by allowing people to escape from the congestion of daily life (Amin, 2008) and that it is the place, "belonging to everyone, not to anybody in particular" (Rowe, 1997).

From this perspective, Zucker (1959) defines the square as the heart of a city among other public spaces, claiming that its main function is as a gathering place for people where they are humanized by mutual contact; provided with sanctuary from haphazard traffic; and released from the tension of rushing through the web of streets, regardless of size or scale. Webb (1990) conceives the square as a microcosm of urban life, a place where people can meet and watch the world go by. From the Baltic to the Mediterranean, and through the heartland of Europe, the square, in all its varied forms, seems to be an indispensable part of daily life; a place for freedom of action, regardless of the presence of strangers sitting or strolling next to us (Kostof, 1992).

Krier (1991) claims that squares were probably the first use man discovered for urban space. In the private realm, their use corresponds to the inner courtyard of a group of buildings; while in the public realm they may take on the roles of market place, parade ground or as a ceremonial square in front of churches and town halls. According to Moughtin (2003), the square is the ideal setting for public and commercial buildings in the city. Sitte (1889) points out that the square is at the very heart of the city and retains a vital functional role for community life, and he extolls the harmony that exists between the square and its surrounding buildings.

In this sense, public space in general and the urban square in particular may be defined as an "organized space," (Tibbalds, 2001), as an exhibition of "order for the whole" in an interrelated pattern of buildings and circulation routes, blocks and streets, squares and courts. Ford (2000) asserts that traditional cities comprise a variety of public spaces that are inclusive for all members of the public, and where quality derives more from the nature and memorability of spaces than from the individual buildings themselves. However, while the square can be conceptualised within the whole city and in relation to other public spaces within an allencompassing scheme, it may also be isolated from the urban fabric and become conceived as a separated entity and a mere void (Zucker, 1959).

From a functional perspective, the most successful way of ensuring a lively and interesting environment is to designate a set of activities within a public space (Llewelyn-Davies, 2000; Moughtin, 2003). In his comprehensive and influential study, Gehl (1996) classifies the types of activities conducted in public spaces as necessary, optional and social, and asserts that these activities must be an integral part of the interaction of the physical environment. Kostof (1992) also stresses that the less specific the form of the square, the more possible it is to have a public space of mixed uses. A square might be used as a market place, while also being used to host sporting events on some days of the year. Plaza Mayor in Madrid, Spain is an arena for sporting events, but also utilised for almost every other purpose. Public spaces with a sense of fixed use are very rare.

From a socio-political viewpoint, Rowe (1997) suggests that the problem of declining public spaces is linked more to uncertainties in the appropriate relationships between the state and civil society than to inadequate design. 
He believes that the use and shaping of public spaces is satisfactory in cases where a well-balanced relationship between the state and civil society exists. In some cases the private sphere appears to be on the ascendancy and private realms dominate urban environments, while in others, the authoritative splendour of the state is dominant.

In many parts of the world people are becoming dissatisfied with the poor design of public spaces, which have become dominated by parking, road infrastructure and have a poor sense of place (Carmona et al., 2008). Tibbalds (2001) points out that the fundamental problem is that many of the world's towns and cities have become threatening places - full of litter; polluted and congested by traffic; marred by mediocre, ugly and poorly maintained buildings; and are unsafe. When urban public spaces, especially in the city centres, become unattractive, people are more likely to retreat to the suburbs (Whyte, 1980), and this withering of the public realm has become a common trend in recent decades (Banerjee, 2001).

Associated with this trend, public space has become a space to be moved through rather than a place to be, which has led to homogenisation with no consideration of the diverse needs, interests and preferences of the different participants in everyday urban life (Carmona et al., 2008). The private realm has begun to flourish, with emphasis on privacy, personal comfort, private consumption and security (Tibbalds, 2001). Shopping malls, corporate plazas and other such places have increased in popularity (Banerjee, 2001).

Günay (2009) criticizes these views as being an aspect of Cartesian thought, in which the matter is conceived to be the projection of mind. Referring to Heidegger, he draws attention to the need to develop an ontological discussion that relates the formation and transformation of urban space to the existence of human beings. On this account, according to NorbergSchulz (1984), who stressed the need for a qualitative point of view for interpretations of urban space, it is meaningless to imagine any event without reference to a locality. Place is more than an abstract location. It has "environmental character," the essence of place, through the totality of material substance, shape, texture and colour. According to NorbergSchulz, any place is a qualitative total phenomenon, the meaning of which cannot be reduced to any of its properties. He conceives the structure of place in terms of space, the three-dimensional organisations of the elements that make up a place, and the character which denotes the general atmosphere, which is the most comprehensive property of any place. In his opinion, real presence is intimately linked with character, which is determined by the material and formal constitution of the place, and refers to its genius loci, meaning the spirit of place.

According to Rossi $(1999,103)$, character is dependent upon locus: the relationship between a certain location and buildings that are in it, which makes a place singular and universal. In these terms, the locus refers to the uniqueness of the place. He furthermore conceives the city as a locus of collective memory, where the relationship between the locus and citizenry constitutes its character (Rossi, 1999, 130). In a similar fashion, Boyer (1996, 3) sees the public space and its community as a collective project to bind people together in harmony, and points out that "the public realm of the City of Collective Memory should entail a continuous urban topography, a spatial structure that covers both rich and poor places, honorific and humble monuments, and permanent and ephemeral forms; and should include places for public assembly and debate, as well as private memory 
walks and personal retreats. Having lost this understanding, the spatial form of the contemporary city has become "a patchwork of incongruous leftover pieces alongside a set of artfully designed compositions" (Boyer, 1996, 9).

From a morphological point of view, public spaces, and urban squares in particular, are considered successful if they are part of an organised whole within the public space system. Any intervention into urban space must stem from the comprehension of the nature of its morphological characteristics: "totality of material substance, shape, texture and colour," (Norberg-Schulz (1984). These are produced within a historical process as a result of the relationship between a certain location (Customs Square, as a field of study in this paper) and the buildings in and around it. This relationship, or "locus" according to Rossi (1999), gives rise to the formation of the character of the place and imparts meaning to the place with reference to its locality.

Since this study aims to explore the transformation process of Customs Square into a Grand Bazaar it will deal inevitably with the dynamics and relationships that contributed to the formation of the character of the place and its existence that made the place singular and universal, and reinforced the change in its meaning. This transformation is explored within two periods in Mersin's history: firstly, the period from its foundation years to the middle of the twentieth century, when the new port area was constructed; and secondly, the period of development following the construction of the new port.

\section{CUSTOMS SQUARE:}

\section{THE PUBLIC SPACE OF THE INTERNATIONAL CONTEXT}

The growth of Ottoman-European trade during the nineteenth century gave birth to a number of port cities (Sifneos, 2005), one of which was Mersin. At the beginning of the nineteenth century, Mersin, in the Çukurova region, comprised "a few huts on the shore," as described by Beaufort (1817); while only a few decades later, Habeeb Risk (1853) defined the city as "a small village of 50 huts, where fellahs constitute the majority of the population". Likewise, Barker in 1853 reported that trade in Mersin port had increased considerably. French vessels sailing to Marseille were loaded with sesame seed and wool, Arabian vessels transported goods to Syria and Cyprus, Greek boats came to load wheat, and English vessels transported goods to İzmir.

What made the city of Mersin different from the other port cities in the region was the emergence of the city from almost nothing in the first half of the nineteenth century. Selvi Ünlü (2007) suggested that the growth of the city was a result of the commercial relations across the Mediterranean region and beyond, the competitive nature of the imperialist core, and trade with France, Britain, Germany and America, which saw the Çukurova region as a focal point of development.

Customs Square, the focal point of commercial activity and the main square of the city, was located near the coastline, as was the case with many other port cities, and formed a gateway to the outside world as an extension of Customs Pier. The name Customs Square originated from the main building on the site - Customs House - while other surrounding buildings housed shops, hotels, restaurants, cafes and a mosque. On some postcards from the period, the square was referred to as Place de la Fontaine due to the 
Figure 1. Views of Customs Square from postcards of the period (Personal archive of Ali Murat Merzeci).
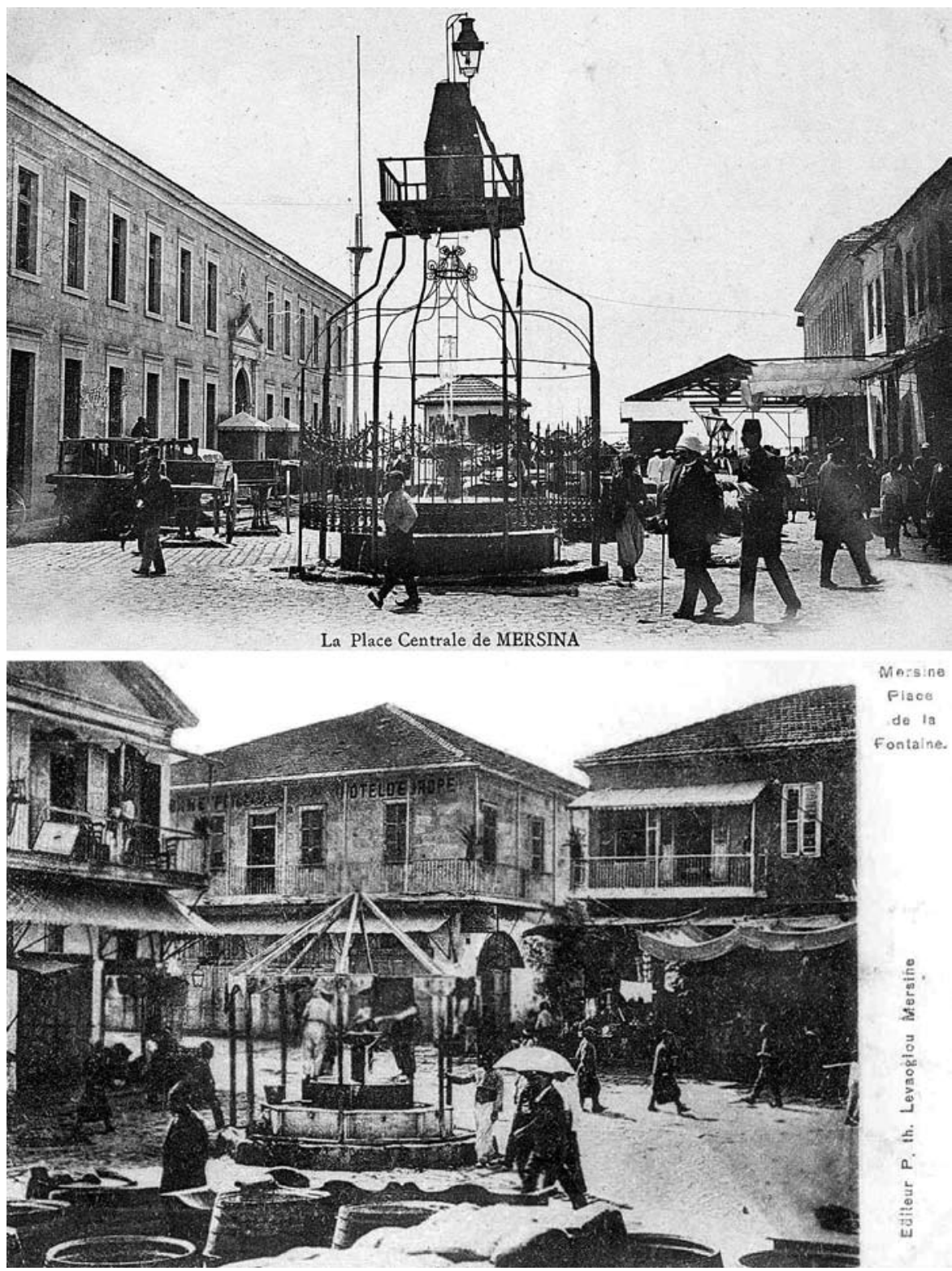

central feature of the square, or as La Place Centrale de Mersine (Figure 1). Oğuz (1924) wrote that those who arrived in the city by ship disembarked into a pleasant square with a flowing fountain. The surrounding buildings formed the physical boundary of the square, and the variety and diversity of activities in the square brought a lively atmosphere to the area.

When taken into consideration as part of an interrelated block and street pattern, Customs Square existed as an integral part of the city, and even of the outside world in terms of international trade relations. Located on the waterfront, the square was an organic part of Customs Pier - the most important pier in the city - outranking Stone Pier, Municipal Pier, German Pier and Railway Pier. In this respect, the existence of Customs Square was highly dependent upon the existence of Customs Pier, and the two formed a consistent whole, linking not only Mersin but also the fertile agricultural land to the industrial core. In summary, Customs Square, together with 
Figure 2. The ground plan of Customs Square and the buildings around it, 1910 (Republican Archives of the Turkish Prime Ministry, TCBCA).

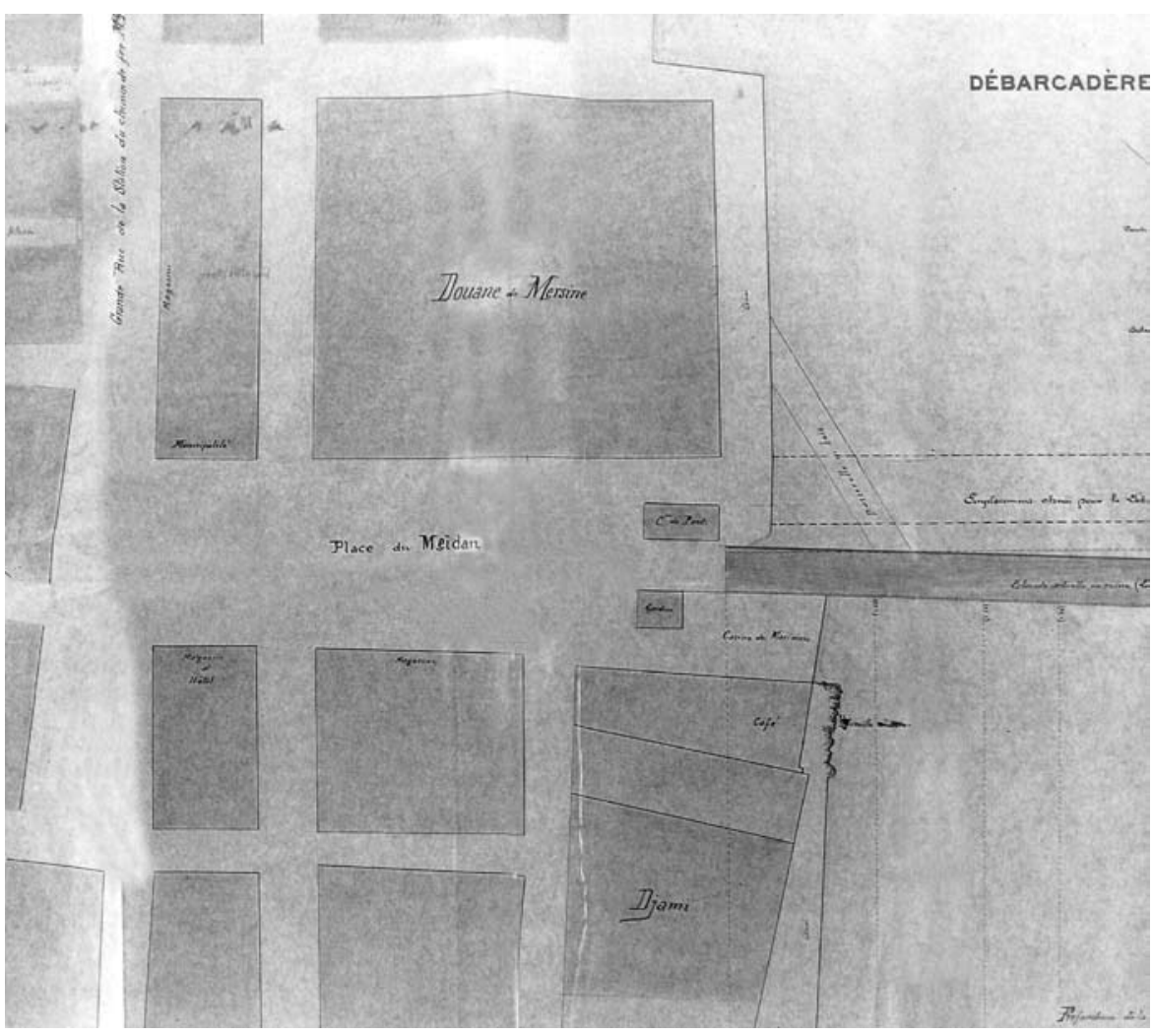

Customs Pier, were an integral part of the developing international trade relations.

Customs House supplemented the integrity of Customs Square and Custom Pier, offering a daily reminder of the city's importance for international trade, being linked closely to the inner commercial relations incorporated within Customs Square. Other noteworthy buildings lining the square included New Mosque, located along the shoreline to the west of the square, as well as coffee houses, retail shops, hotels and restaurants, all of which were incorporated into the unique identity of Mersin as a mercantile port of exchange in the Eastern Mediterranean (Figure 2).

Besides the international connections, which were a key factor behind the existence of Customs Square, internal connections existed with other public places that together constituted an "interrelated pattern of buildings and circulation routes, blocks and streets" (Tibbalds, 2001). Uray Street and its surroundings formed the eastward extension of Customs Square, and, like Karaköy in İstanbul (Tokatlı and Boyac1, 1999), developed as a business centre that was especially associated with international trade and banking. Besides banks, many international companies and their representative offices, including insurance agencies, shipping agencies, commissionaires, and import and export dealers began to open for business along the street in the merchant inns; and companies and agencies operating in the finance and insurance sectors flourished alongside the increasing commercial activity. The relationship between Customs Square and Uray Street was strengthened with the establishment of the "Dekoville," a narrow-gauge rail system that ran along the street, by which goods and chattel were conveyed between Customs Pier and the railway station. In this way, the 


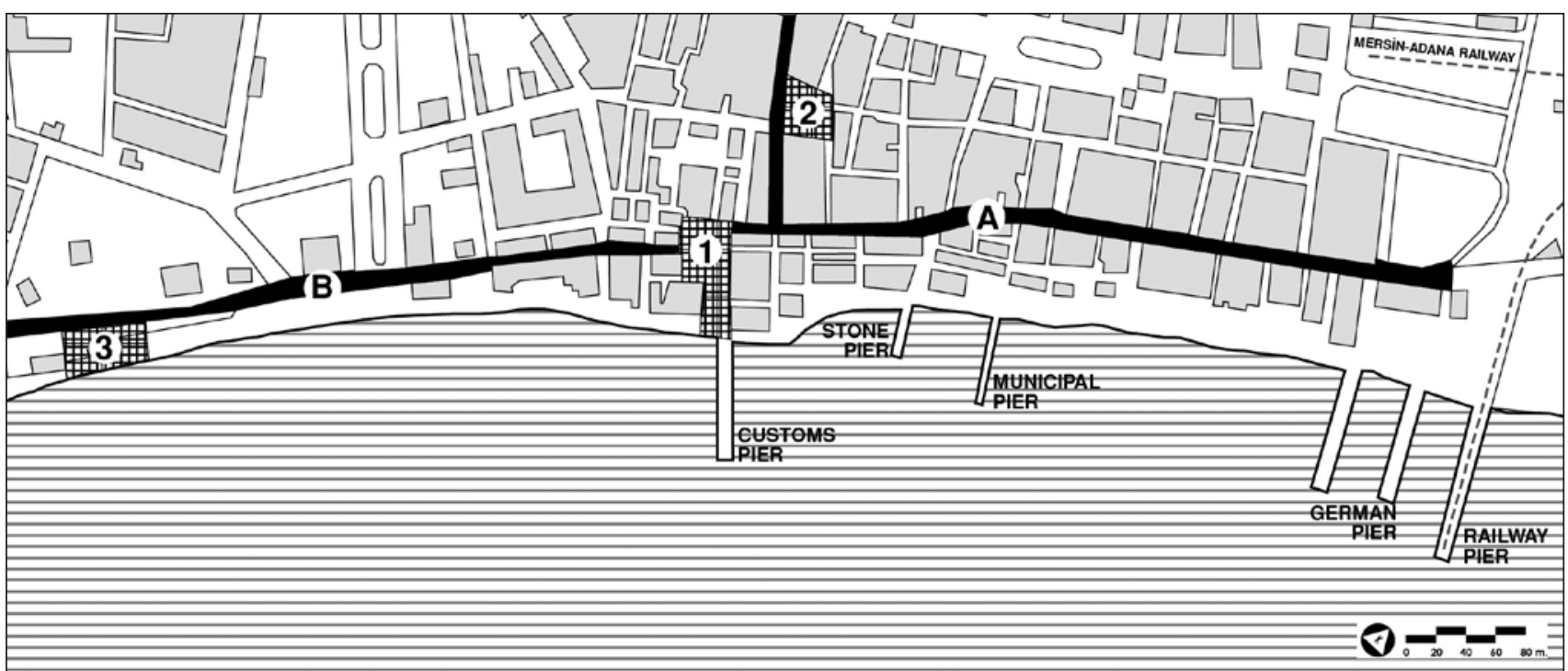

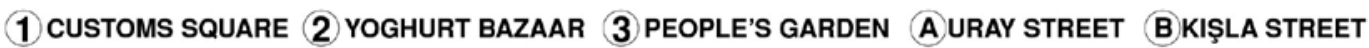

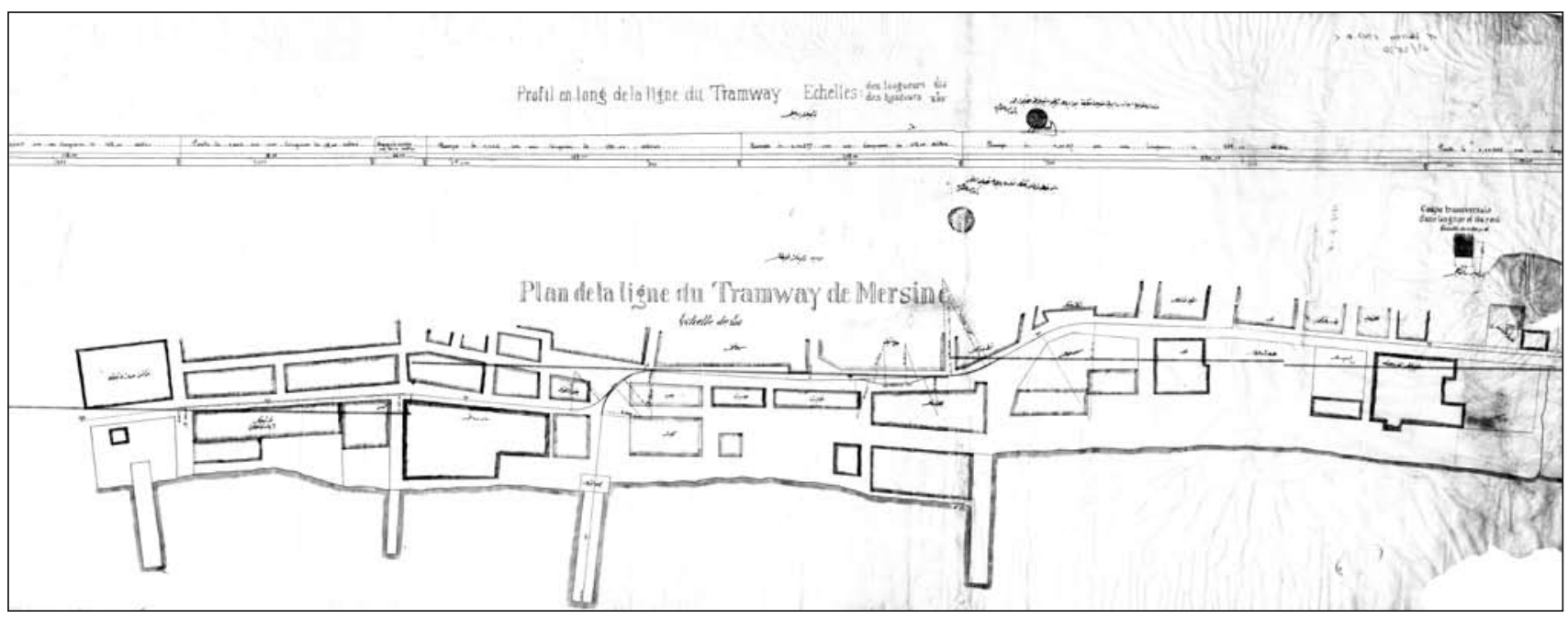

Figure 3. Customs Square within the public space system of the city until the middle of the twentieth century.

Figure 4. The project for construction of the tramline $t$ along Uray Street, 1888 existence of Customs Pier was supported by the commercial activities in Uray Street and the international relations of merchants in the area.

On the northern extension of Customs Square, the Yoghurt Bazaar was a traditional market place for the trade of agricultural and animal products. Nomads and villagers would trade salt, leather, wool, fruit, vegetables and daily products. To the west of the square, Kışla Street functioned as a retail ribbon, where the retailers were predominantly drapers and shoe sellers. Connected to Kişla Street in the western part of the city the People's Garden was established as a meeting place for the general public, featuring an open-air cinema and other forms of public entertainment (Figure 3).

In this period, several interventions into the urban built environment, including the construction of a tramline along Uray Street and improvements to Customs Pier, directly affected Customs Square, and improved its meaning within both the public space system and international relations. According to the Ottoman State Archives, the 
1. Ottoman State Archive Records of Turkish Prime Ministry (BOA.I.MMS.102/4320).

2. Center des Archives Diplomatiques de Nantes, Cilicie, carton no. 303.

3. Ottoman State Archive Records of Prime Ministry, Turkey (BOA.Y.A.RES.1027/2522).

Figure 5. The project for the pier, proposed in 1895 to replace the Customs Pier (Ottoman Archives of the Turkish Prime Ministry-BOA.DH.MKT.305/17). construction of a tramline was first discussed in the late-nineteenth century, with a document dated 25 August, 1888 describing a $1.35-\mathrm{km}$. route (Figure 4) that would start in Customs Square. It was suggested at the time that private companies be granted concessions to build the tramline, and as revealed in the same document, other tramlines were also being considered for Tarsus and Adana (1). It can be followed in both the Ottoman State Archives and the French Diplomatic Archives that despite efforts during the last decade of the nineteenth century, the tramline was not constructed until much later, and was finally opened with a ceremony on 10 March, 1920, when Mersin was under French Rule (2).

Another intervention that raised the profile of Customs Square was the enlargement of the customs area through the reclamation of land from the sea and the improvement of Customs Pier. During the Ottoman period, from the mid-nineteenth century to the 1920s, improvements to the existing piers and the construction of a new port were planned many times. In a report dated 31 December, 1888 it was suggested that $600 \mathrm{~m}^{2}$ of land should be reclaimed from the sea to form an area for storage to handle the flourishing commercial activities and improve the efficiency of customs procedures (3). A new pier was also proposed to replace the

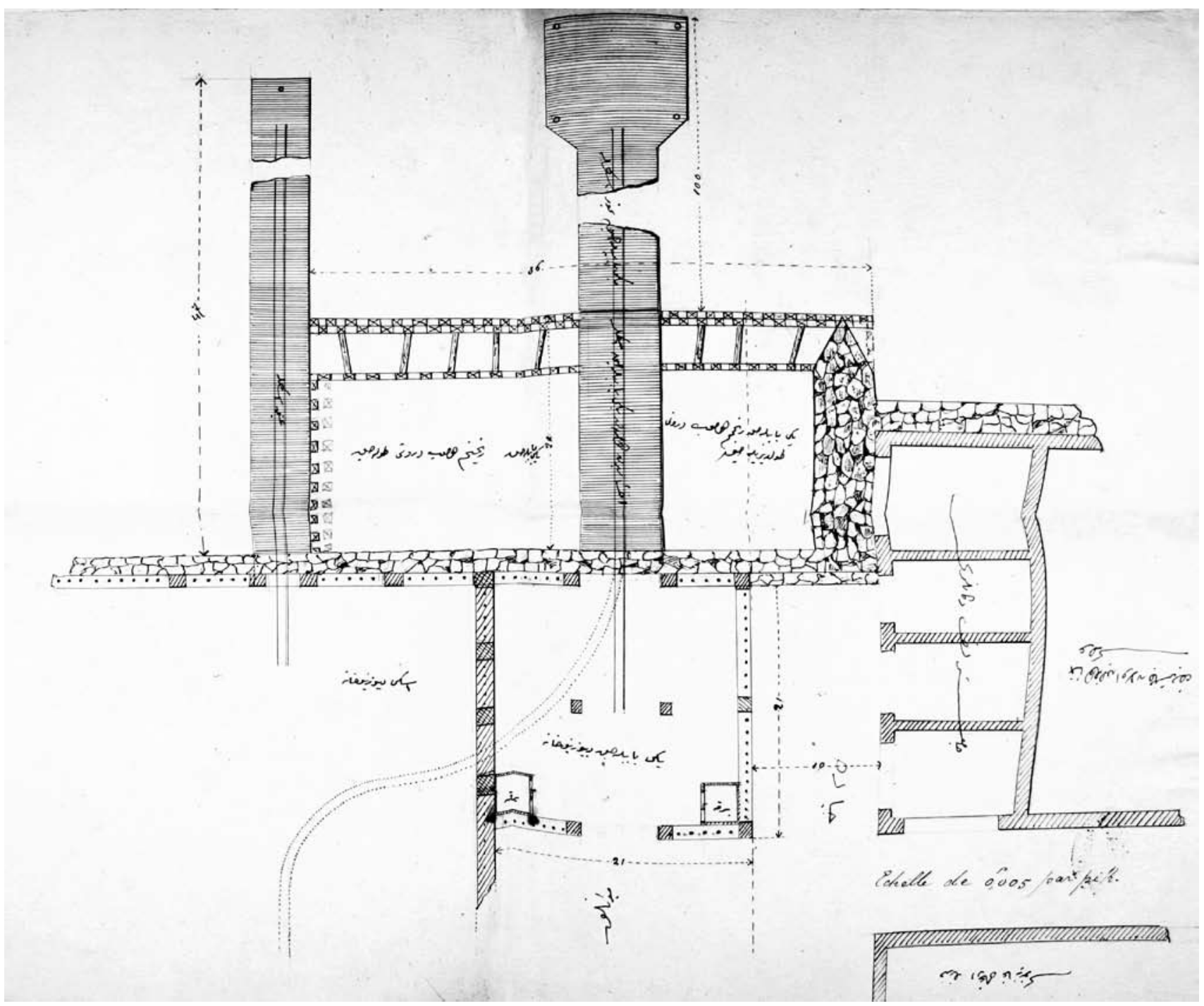




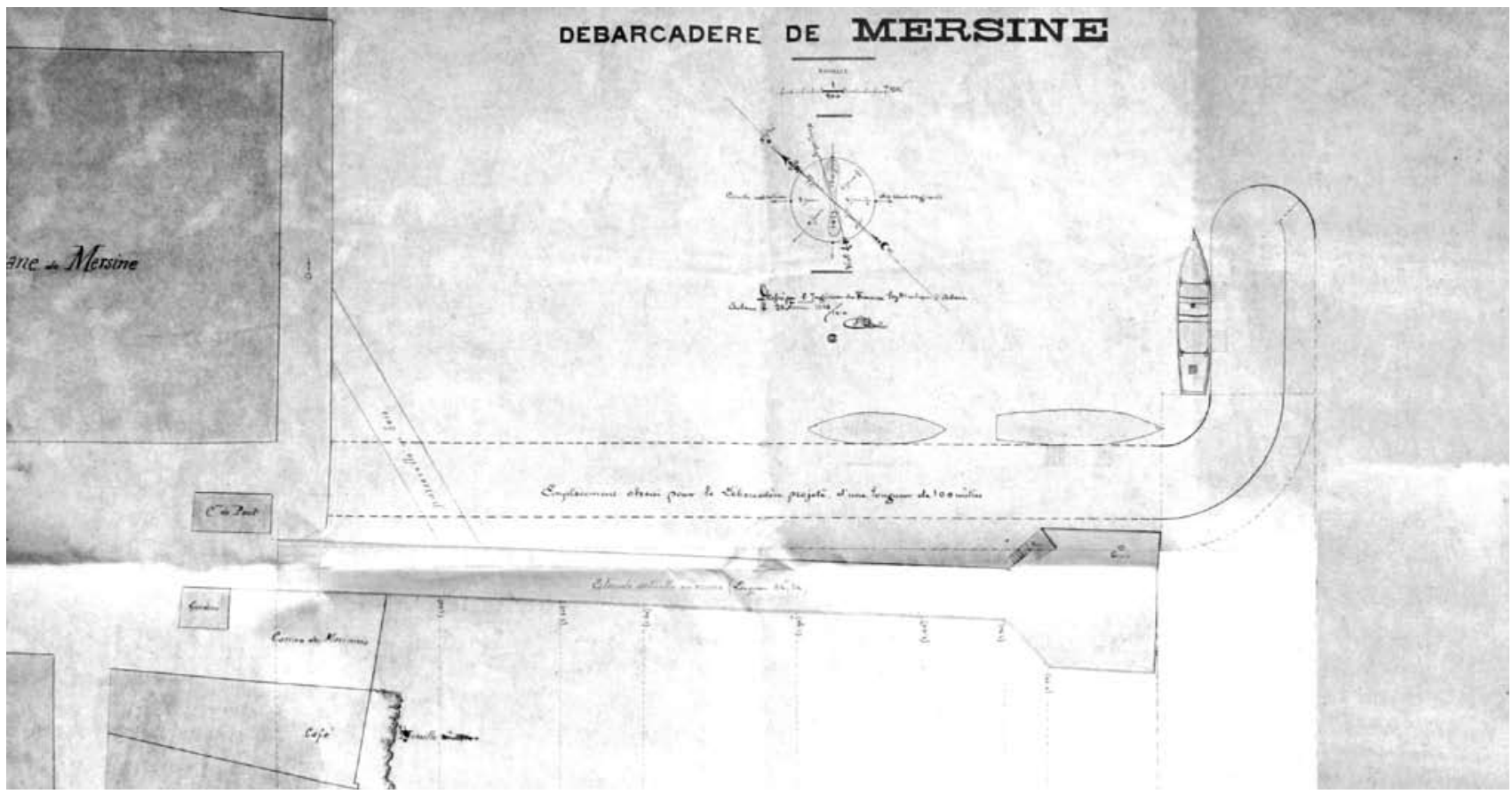

Figure 6. Project to improve the condition of the Customs Pier in 1910 (Republican Archives of the Turkish Prime MinistryTCBCA.37199)
Customs Pier (4) (Figure 5). Merchants and consuls were pioneering the construction of a new port and were making improvements to the existing piers, not only through the provision of financial support, but also, and more importantly, through reports to the central government. Among them, one dated 18 December, 1913 prepared by the Mersin Chamber of Commerce was probably the most significant, containing suggestions for potential interventions to develop the port facilities that were defined in detail. The Chamber proposed further works to ensure more efficiency after a meeting organized with involvement of many prominent merchants and commissioners. The works, to be completed immediately, included the
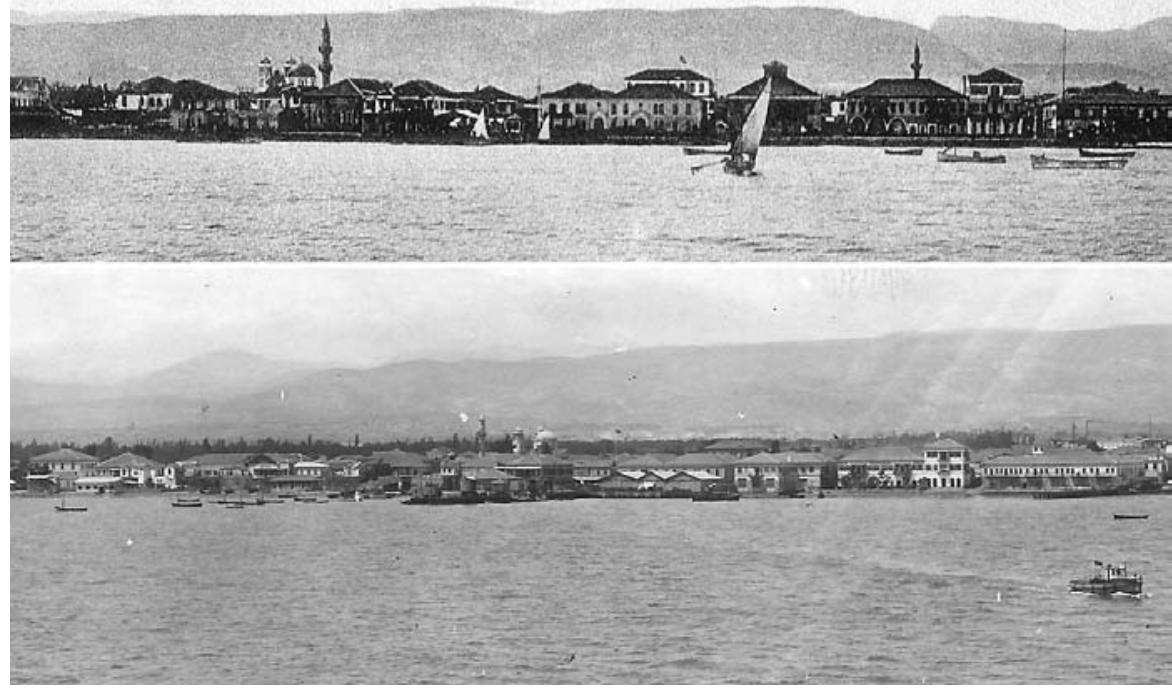
4. Ottoman State Archive Records of Prime Ministry, Turkey (BOA.DH.MKT.305/17).

5. Center des Archives Diplomatiques de Nantes, Cilicie, carton no. 303.

6. Center des Archives Diplomatiques de Nantes, Monographie de Mersine, CADN, carton no 203, Adana. illumination of the pier and the construction of a storehouse as part of the Customs House (5) (Figure 6). The project was developed in 1910 by the Governorship of Adana, but there is no evidence that the pier was actually constructed.

Attempts to improve the existing piers and to construct a new port continued during French Rule after 1919. In this period, the poor state of the Customs Pier was again highlighted, and consequently construction works to improve the pier and to build a new one were begun on 10 May, 1920 and lasted until October. The result was a pier that was 110 meters in length and 12 meters wide, illuminated with suspended lights, and connected to the city along two dekoville lines, one leading to Customs House and the other to the railway station (6). It is apparent from photographs from the period that Customs Pier and the new embankment areas were constructed during French Rule (Figure 7).

In summary, the existence of Customs Square from the nineteenth century to the middle of the twentieth century was basically dependent upon the character of Mersin as a port city in the Eastern Mediterranean, international and regional trade relations. The Customs Square was a singular and unique place that acquired a character and atmosphere on the basis of, on the one hand, its relation to Customs Pier and Customs House, and on the other, its relationship with the coffee houses, hotels, restaurants, retail shops and grocers located around it.

Furthermore, Customs Square acquired its character from its importance for the citizens of Mersin, which was based on the well-balanced relationship between civil society and the state, and in particular the efforts of merchants engaged in international trade who supported the improvement of Customs Pier, one of the defining components of the essence of Customs Square. Oral history narratives of witnesses from the period, made specific mention of the most notable traders around Customs Square, including the drapery and haberdashery shops of the Işıkara, Nane and the Özcan families; the grocery stores, among which the most prominent were Kayseri Bakkaliyesi, Konya Pazarı and Yunus Bakkaliyesi; and patisseries, with Mersin Pastanesi being the best known (Ünlü and Selvi Ünlü, 2012).

Reminiscences of local people from the time also indicate that the buildings around Customs Square were in use by a wide range of people in terms of religion, ethnicity and culture, resulting in a cosmopolitan urban culture that gave Mersin in general and Customs Square in particular "the conviviality of a pluralistic society and a dynamic contiguity of groups" (Driessen, 2005).

All of the above lead to an understanding that Customs Square and its character were dependent upon the existence of Customs Pier and Customs House, being products of the international trade relations of the town. Besides this integrity, Customs Square owed its existence and character also to its relationship to other buildings that hold a significant place in the collective memory of the city. Customs Square was shaped and acquired its character within a well-balanced relationship between civil society and the state during the centennial period after the city's foundation.

This settled relationship and pattern was recognised and supported by Hermann Jansen when preparing the first development plan for Mersin, issued in 1938, after he had completed the first development plan for Ankara, the capital of the young Republic. His plan report stated that 


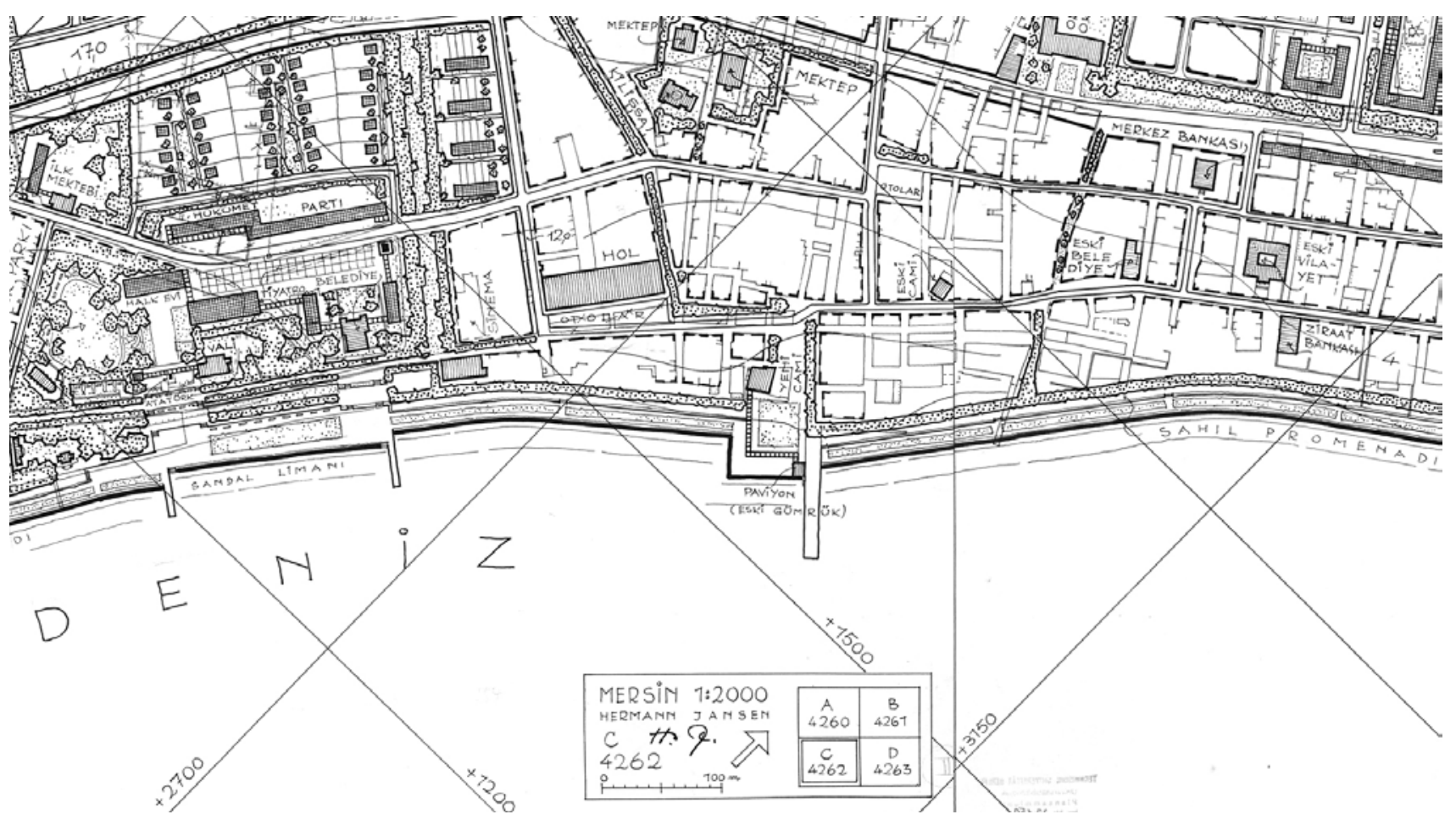

Figure 8. A section of the development plan prepared by Hermann Jansen for Mersin, issued in 1938 (Architekturmuseum, Tecnische Universitat Berlin, Inv.-Nr. 23458). the city of Mersin owed its character to its relationship to the sea and its trade relations, and although he proposed a new port area on the eastern extension of the city, he preserved the settled pattern at the very centre of Mersin, including Customs Square and the buildings around it. Furthermore, he suggested linking the square to the promenade he envisaged to run along the shoreline (Figure 8).

\section{GRAND BAZAAR: A PUBLIC SPACE OF THE NATIONAL CONTEXT}

Starting in the 1950s, Mersin underwent a rapid population increase due to an inflow of people from rural areas who had faced redundancy under the economic policies of the new government that prioritised the modernisation of agriculture. Owing to the nationalist policies of the early Republican period, the multi-cultural pattern of the city, in which mostly the Levantine and Greek populations had led the field in international trade and developed relations with the industrial core, was modified into a more monolithic one. This change was experienced by all Mediterranean port cities at the time, and led to a rapid homogenisation of their cultural make-up - Mersin became more Turkish, as "Trieste became more Italian, Thessaloniki became more Greek, Tangiers became more Moroccan, and Alexandria became more Egyptian" (Driessen, 2005). This led the new nation states to create a new regional system, rather than make use of port cities that had become connected to international networks (Keyder, 2010). International trade relations turned into a more centrally directed form after establishment of nation states. The capital of each state became centre of international relations. Port cities more generally began to lose their strong positions within international relations.

Due to these demographic, economic and socio-political changes, Mersin evolved into a port city within a more national context of the new Republic. Within this framework, Mersin faced large-scale interventions 
into the built environment by both central and local governments that resulted in significant changes to the public space system. They had direct implications for the character of Customs Square. The most important of these interventions was the construction of a large new port on the east side of the city, comprising not only docks, but also storage facilities. The construction required the reclaiming of land from the sea and the demolition of the existing piers, including Customs Pier, which had been an essential part of the character and atmosphere that had developed within Customs Square. The constructed "platform," skirting the old coastline in an east-west direction, extended 100 meters into the sea, thus breaking the connection between Customs Square and the seafront, and causing a subversion of the organic relationship between the sea and the square. As the square was no longer located directly on the waterfront, as is generally the case in port towns, it was transformed into an inner-city square.

As a further consequence of the construction of the new port and the removal of Customs Pier, Customs House lost its raison d'etre. The character and atmosphere of Customs Square went into decline, and it began to recede from being a total qualitative phenomenon as the integrity of the square with pier and Customs House. Therefore, beginning in the 1960s, redefining Customs Square and developing a new set of relations between the urban space and buildings around it in the very heart of the city became one of the main problems of local government.

Articles in local newspaper Yeni Mersin (New Mersin) in 1964 and 1965 stated that the intention of the Municipality of Mersin was to demolish a number of buildings in the square, including Customs House, and replace New Mosque with a larger one so as to allow for an increase in area of the main square at the centre of the city. These incremental interventions resulted in the demolition of most of the buildings, including prominent retail shops such as Mersin Pastanesi, Işıkara Mağazası and Konya Pazarı, each of which held a significant place in the collective memory of the city. The demolition of these buildings brought about a decline in the essence of the square and its relationship with the surrounding buildings, which had been integral to its existence.

In terms of Boyer (1996) Customs Square was thus turned into an incongruous leftover space within the spatial form of the contemporary city. It still maintained its status as a central location, but after the demolitions, the square began to resemble "a place that had been left over after planning, being visually unattractive and awkward, and functionally useless" (Tibbalds, 2001). The area came to be known for its parking, road infrastructure and poor sense of place (Carmona et al., 2008), and developed as a transfer point in the public bus transportation system of the city (Figure 9).

Customs Square lost its direct relation to the sea with the construction of the platform on which İnönü Boulevard and a public park were constructed. This became the focal point for the construction of new buildings, the heights of which were defined by the development bylaws of the period. Being the widest road in the city, the highest buildings in the city were supposed to occur along İnönü Boulevard, one of which was Mersin Hotel, which faced the road on the south side and Customs Square on the west. This was one of the first high-rise buildings in the city, and it triggered the erection of further tall buildings throughout the city centre, especially on the plots with frontages to İnönü Boulevard. This is clearly 
Figure 9. Customs Square, after the construction of a platform on land reclaimed from the sea, and the demolition of Customs House, the buildings around it and the removal of Customs Pier (Personal Archive of Tülin and Tolga Ünlü).

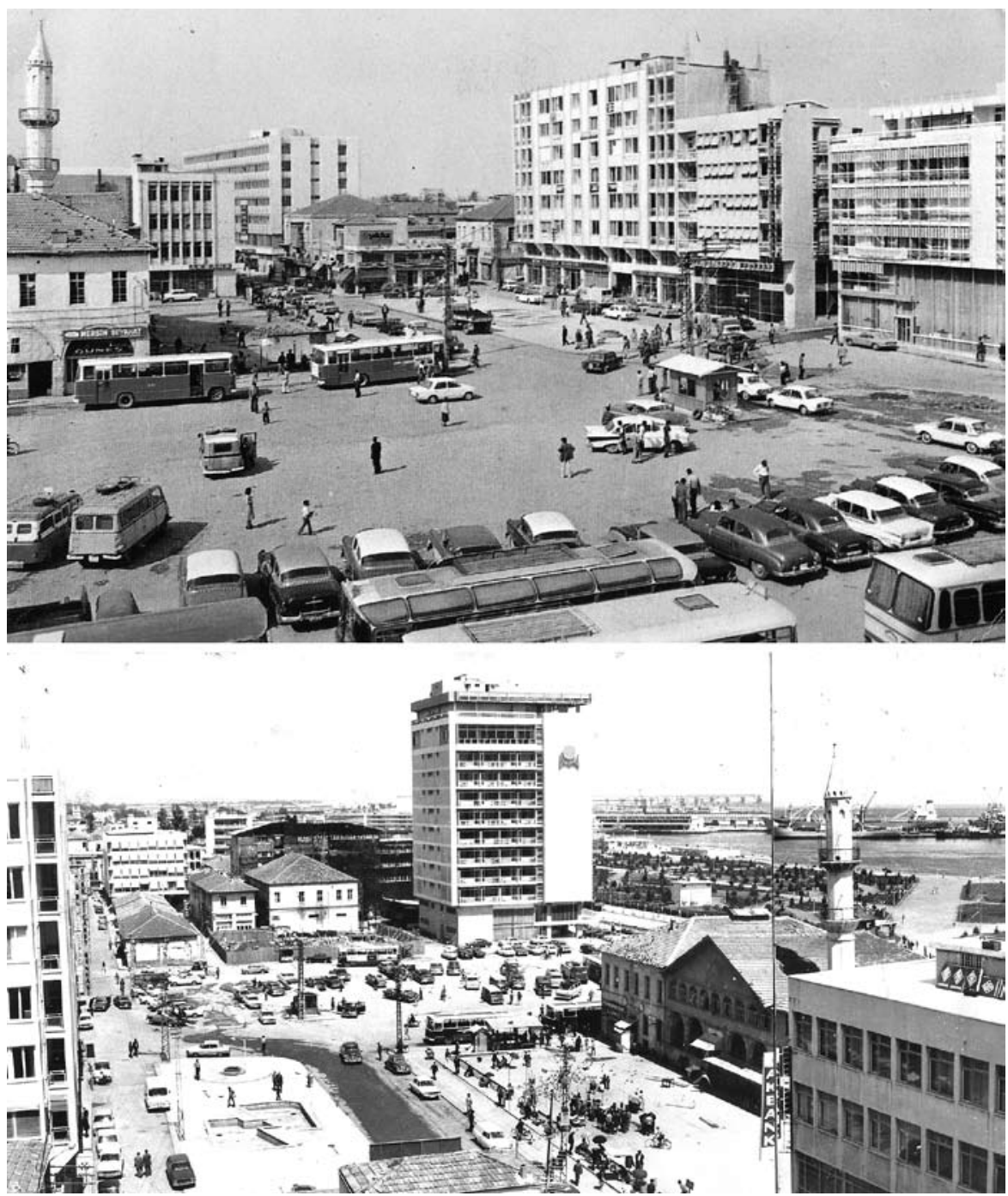

apparent from the pictures, which document the change in the silhouette of the city over a twenty-year period between the 1960s and 1980s (Figure 10).

The relationship between Customs Square and the buildings around it began to change. Consequently, a new design project was proposed by the Municipality of Mersin in the 1970s. The project was developed by one of the most prominent architects of the period, who also took the responsibility of preparing a master plan for the city at a strategic level. As stated in the plan report, one of the main problems of the city centre was conceived as the high-rise development along İnönü Boulevard, which had been triggered by the development bylaws. It was pointed out that this formation broke the relation of the city to the sea, which was a problem that was aimed to be addressed in the plan. The intention in the plan was not to extend the city towards sea over the reclaimed land, but rather to develop main corridors of public spaces, originating from the inner parts of the city centre and extending to the coast. Customs Square was chosen as the main public space within one of these corridors, and the intention was to connect it with the sea and the anticipated commercial development that would include a mosque, hotel, and social and cultural facilities to meet the demands of the developing tourism sector (Vanl1, 1976). 

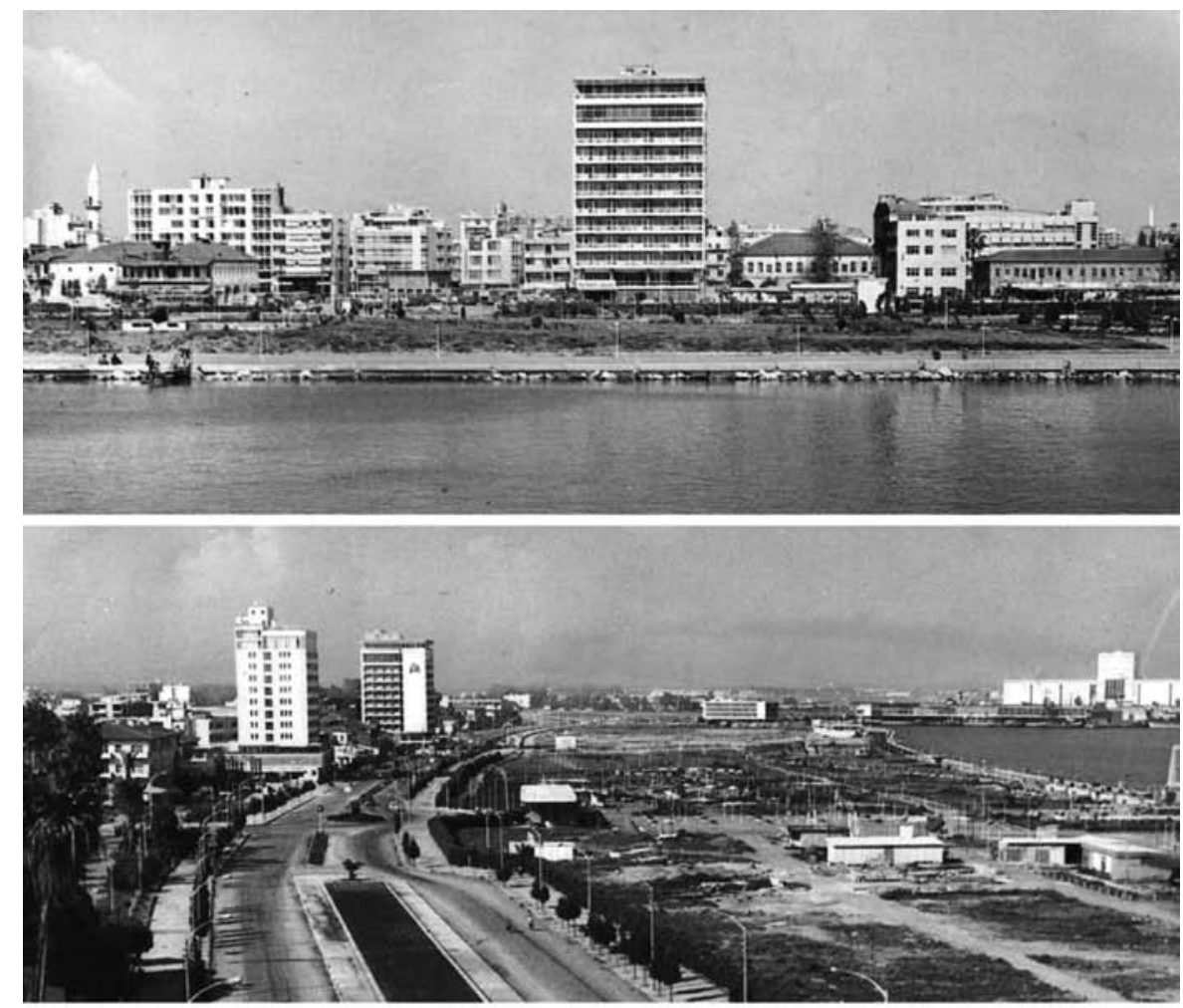

Figure 10. Mersin Hotel, and other buildings that were developed along İnönü Boulevard after its construction (Personal Archive of Tülin and Tolga Ünlü).
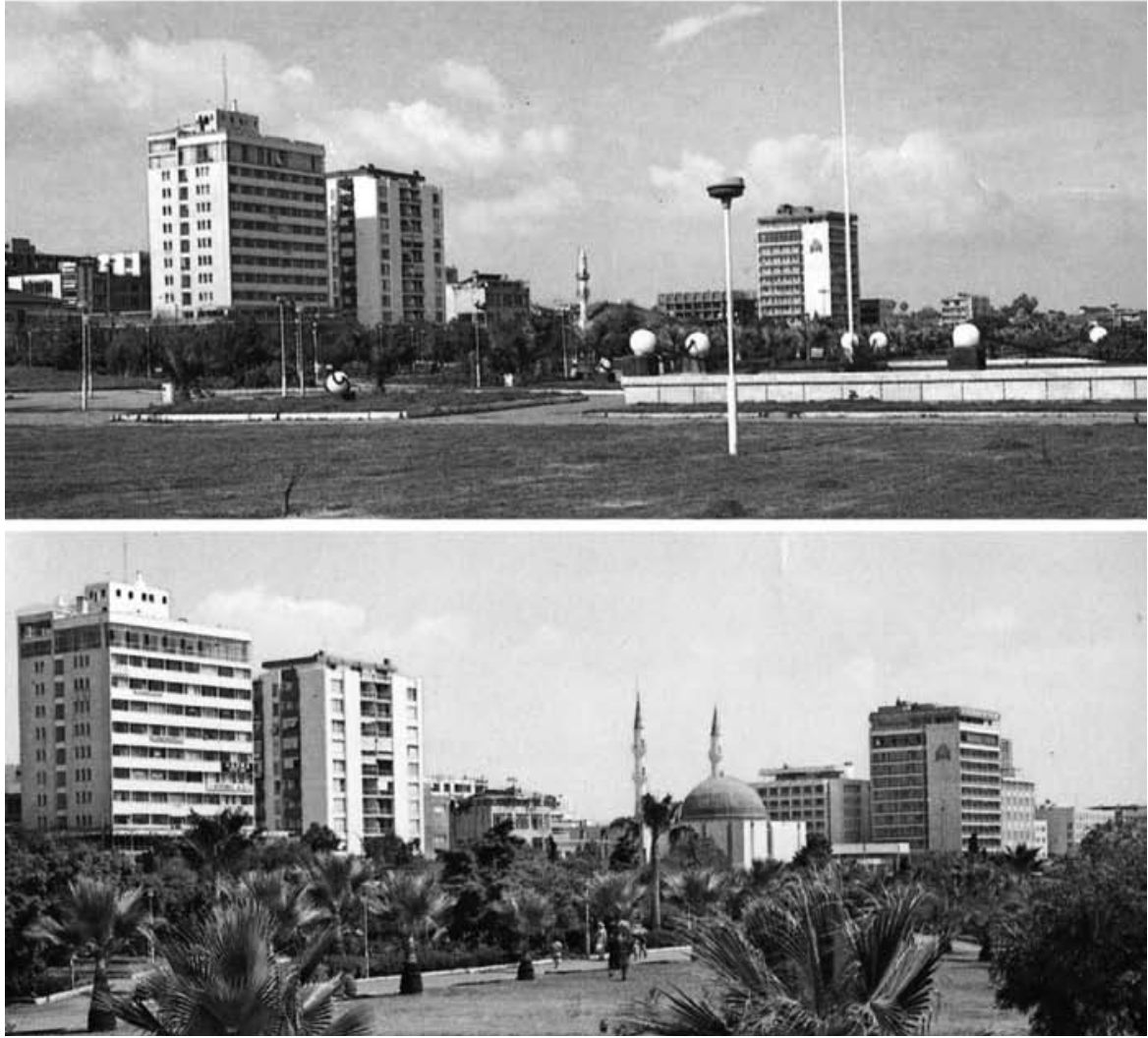

The project was to be carried out in two phases, the first part addressing Customs Square and its surroundings, and the second dealing with the new formations on the reclaimed land as an extension of the square to the sea (Figure 11). 
Implementation of the first phase began with the construction of the Grand Mosque on the southwest of the square on the site of the New Mosque from the previous period, and the building of new retail shops around the square where Mersin Pastanesi, Konya Pazarı and Işıkara Mağazası had existed. At present, newly built retail shops still exist around the square, however in an insufficient way to set a new relationship with the square, and thus fail to add character or atmosphere since the second phase of the project that would have linked the square with the sea, which had been the essence of Customs Square throughout its history, was never implemented.

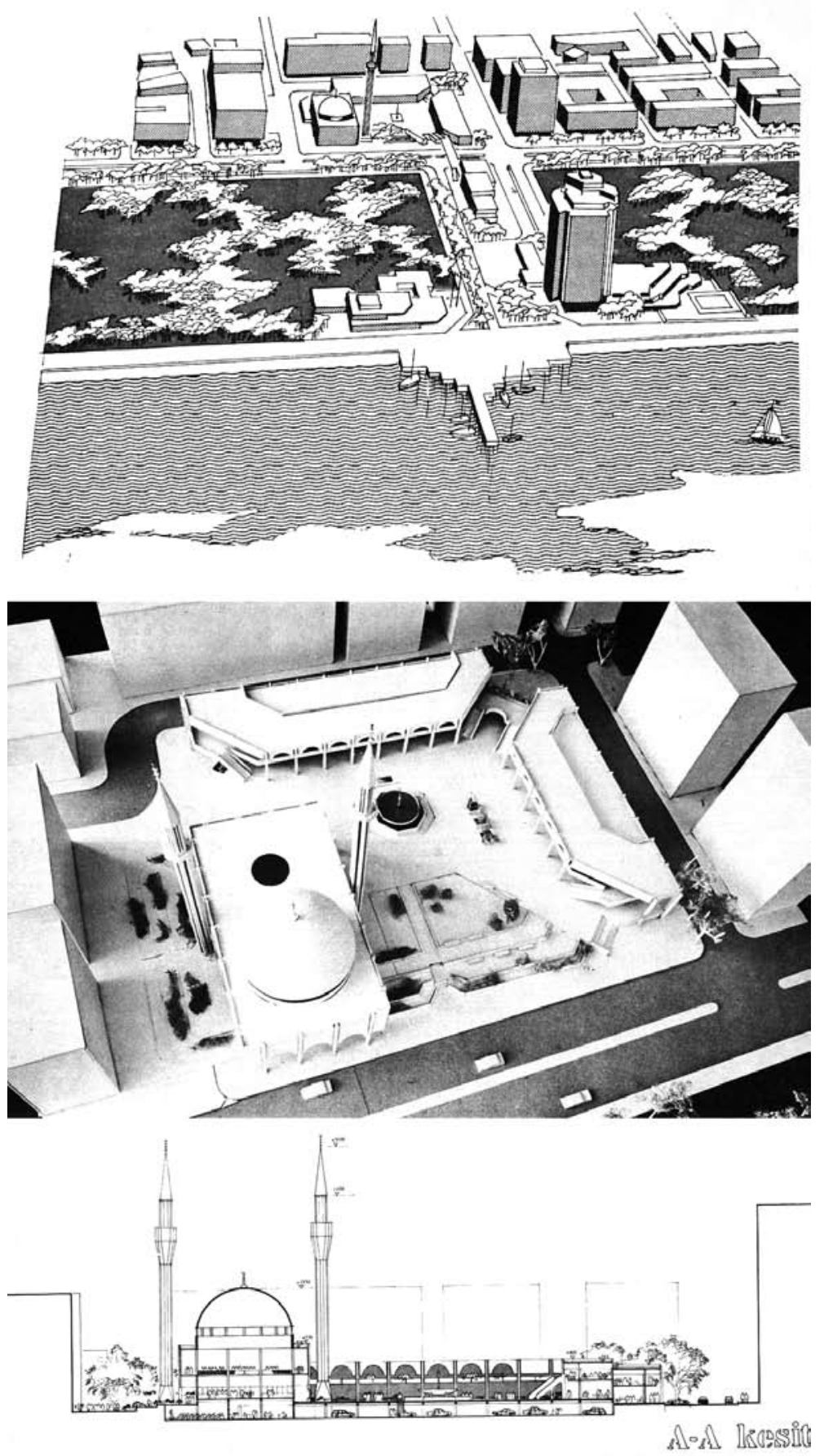


The new design project stemmed from the comprehension of the morphological characteristics of the place, its "totality of material substance, shape, texture and colour" (Norberg-Schulz, 1984), which had been the result of a process throughout history in which the relationship between the square and buildings around it was defined. Originating from this analysis, it was intended to revitalise the character, atmosphere and meaning of the square in reference to its locality, and to redefine the locus. However, the integrity of Customs House, Customs Pier and Customs Square had been lost as a result of developments after the mid-twentieth century, and efforts to revitalise the square failed due to the half-finished implementation process. As a result, new components to give essence to the new square were not developed, and thus its character, meaning and atmosphere were not sustained. The square took on the character of "a space to be moved through rather than a place to be" (Carmona et al., 2008).

Today, the square is seldom used by the public, despite being at a central location in the city. Although there are a few coffee houses in the area, the main generator of social interaction in the square is Grand Mosque, especially during the Friday noon prayers. Consequently, the area is today more often referred to as the "Grand Mosque and Bazaar" rather than Customs Square, meaning that not only has the square become an incongruous leftover space, it has also become a "lost space" (Trancik,

Figure 12. Grand Mosque and Bazaar in the present day (Personal Archive of Tülin and Tolga Ünlü).

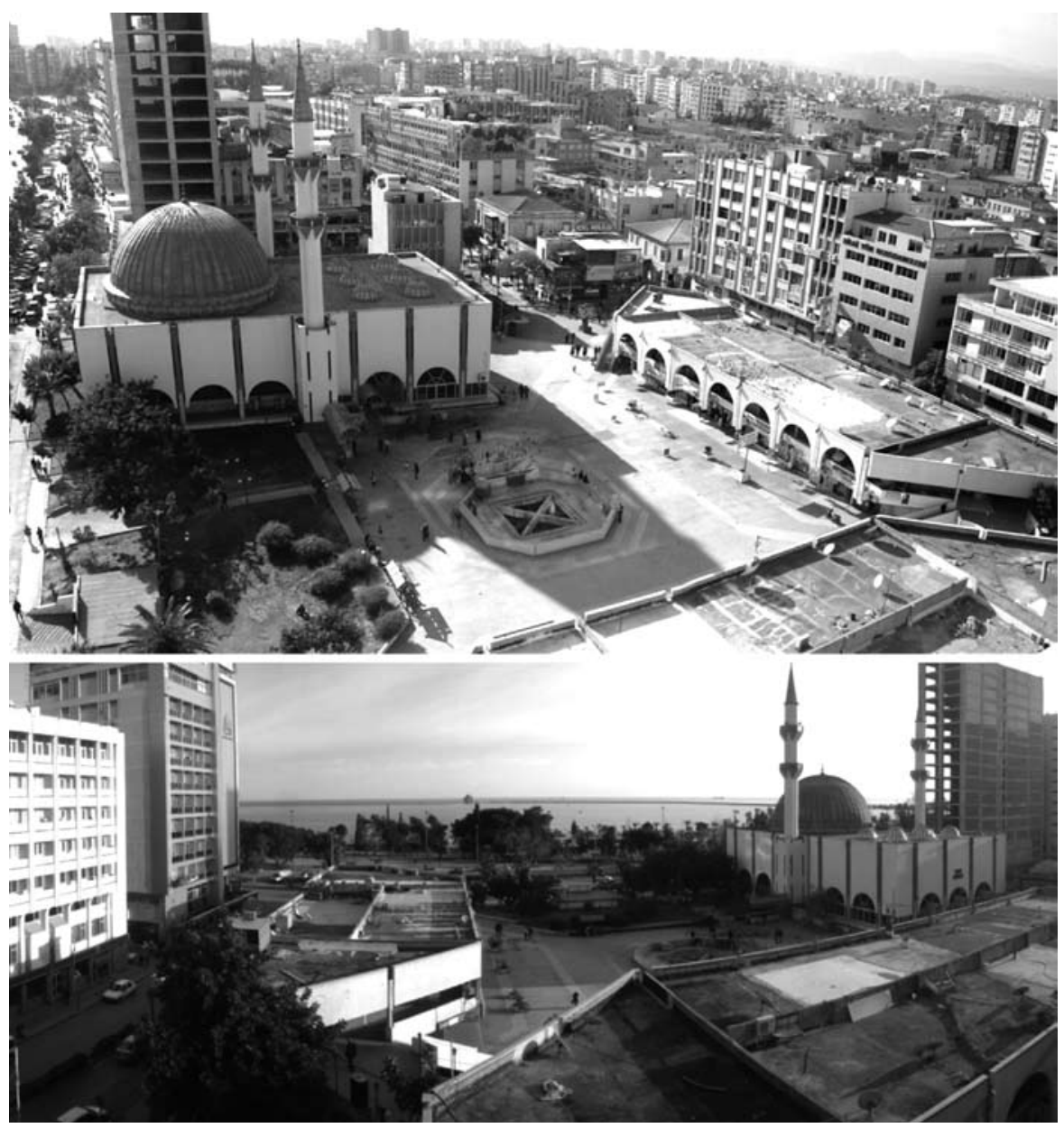


1986) that is unable to contribute positively to its surroundings and users (Figure 12).

\section{CONCLUSION}

This study has discussed the change in the qualitative characteristics of public spaces that constitute their character in relation to urban development and shifts in social processes. In addition it has explored the effect of interventions into the space by urban plans and projects to promote use and create character. In relation to the issues posed at the beginning of the paper

The aim has been to find answers to a number of questions. Since the public use of Customs Square in recent decades is much lower than in the period when Mersin was a small town, is it only a problem stemming from the migration of people from public places to private realms? Or is it a problem of the design of public spaces? Analysis of the transformation began by questioning whether the change was merely a revision of the name of the area, or whether it denoted a substantial change in its essential components, which would inevitably influence its character formation.

Substantial differences have been observed during the transformation of the main square of Mersin from Customs Square into the Grand Bazaar in terms of the shaping of urban space, definitions of its locality and interventions into urban space. Transformation of Customs Square into the Grand Bazaar has been not merely a change of name. The change is a result of reconfiguration of its character.

It has been shown that Customs Square was an integral part of Mersin, and added much to the character of the settlement throughout the century following its establishment in the first half of the nineteenth century.

Components of square's character formation had several aspects in this period. Firstly, they were highly dependent upon the character of Mersin as a port city within an international context. This maintained integrity in its relation to Customs Pier, the main pier of the city, and Customs House, which was an expression of the international trade relations in the Eastern Mediterranean, within which Mersin was flourished. The square was also affected by the buildings around it - the retail shops, restaurants and hotels - that still hold a significant place in the collective memory of the city. Its locus of collective memory owes much to its character influenced from its relation to the citizenship through a well-balanced interaction between civil society and state.

Interventions occurred when the first development plan was prepared in 1938 by Hermann Jansen, who considered the relation of the city to the sea as one of the main components of its existence. Accordingly, he sought to preserve the setting in which Customs Square existed, including the buildings around it, and its relation to the sea.

However, in the course of significant demographic, economic and sociopolitical transformations at both national and international levels, including rapid increases in urban population increase, liberal economic policies and a new hierarchical international order that depended on the power of nation-states, the character of Customs Square, and indeed the city of Mersin, faced substantial changes.

Interventions by both central and local governments resulted in significant changes at both strategic and local scales. The first of these was the 
construction of a new port, for which the Customs Pier needed to be cleared, and the land was reclaimed from the sea in front of Customs Square, breaking its relationship with the sea. The second was the demolition of the Customs House and the buildings around the square in order to create a larger public space, and to redefine the character of the square through a design project that resulted in the construction of Grand Mosque and a number of retail units.

These changes made it difficult to redefine the locus in terms of its relations to both the buildings and the public. As a consequence, Customs Square began to be known as the Grand Bazaar, becoming identified with the mosque and the retail units there; and so the Customs Square, which had once been an integral part of the settlement, was turned into an abstract location, alienated from the collective memory of the city.

It would not be right to believe that a formula from the past would ensure the creation of successful public spaces. Lively public areas that are used by people of all ages with diverse interests and preferences and from all levels of a society can evoke a sense of unity, which in time will be part of the collective memory. To this end, public spaces should be considered as places that are integral part of existence, where the public realm covers all sections of the public and where the constituents of collective memory and the components of its essence will be well-defined. The resurgence of public space must be seen as an integral part of any urban regeneration programme, with public spaces conceived as a whole in relation to the urban fabric rather than as a series of unrelated and competing areas of interest.

\section{ACKNOWLEDGMENT}

The author would like to thank to the editor and anonymous referees for their helpful and constructive comments and suggestions that greatly contributed to improving the paper.

\section{REFERENCES}

AMIN, A. (2008) "Collective Culture and Urban Public Space", City, v:12, $\mathrm{n}: 1 ; 5-24$.

BARKER, W. B. (1953), Cilicia and Its Governers, Ingram Cooke and Co, London.

BANERJEE, T. (2001) "The Future of Public Spaces: Beyond invented streets and reinvented places", APA Journal, v:67, n: 1; 9-24.

BEAUFORT F. (1817), Karamania or a Brief Description of the Southeast Coasts of Asia Minor and the Remains of the Antiquity, Printed for R. Hunter, London.

BOYER, M. C. (1996) The City of Collective Memory: Its Historical Imagery and Architectural Entertainments, MIT Press (Third printing), Cambridge.

CARMONA, M., C. DE MAGALHAES and L. HAMMOND (2008), Public Space: the Management Dimension, Routledge, London.

CARR, S., M. FRANCIS, L.G. RIVLIN, A.M. STONE (1992) Public Space, Cambridge University press, New York.

CERASI, M. (2005) “The Urban and Architectural Evolution of the Istanbul Divanyolu: Urban Aesthetics and Ideology in Ottoman Town Building", Muqarnas, v:22, 189-232. 
CORBETT, N. (2004) Transforming Cities: Revival in the Square, RIBA, London.

COSTELLO, V.F. (1980) "The evolution of retailing patterns" in G. H. Blake and R.I. Lawless (eds) The Changing Middle Eastern City, London, Croom Helm.

DRIESSEN, H. (2005) “Mediterranean Port Cities: Cosmopolitanism Reconsidered", History and Anthroplogy, v:16, n:1; 129-141.

FORD, L. R. (2000) The Spaces Between Buildings, Johns Hopkins University Press, Baltimore and London.

FUHRMANN M. and KECHRIOTIS V. (2009) "The late Ottoman port-cities and their inhabitants: subjectivity, urbanity, and conflicting orders", Mediterranean Historical Review, 24 (2), 71-78.

FUSCH, R. (1994) "The Piazza in Italian Urban Morphology", Geographical Review, vol. 84, no. 4, 424-438.

GEHL, J. (1996) Life Between Buildingds: Using Public Space, Island, Washington.

GÜNAY, B. (2009) Conservation of Public Space as an Ontological Problem, METU JFA; v:26, n:1; 123-156.

KEYDER, Ç. (2008) Europe and the Ottoman Empire in Mid-Nineteenth Century: Development of a Bourgeoisie in the European Mirror. In Cottrell P.L. (ed.) East meets West: banking, commerce and investment in the Ottoman Empire, Ashgate, Hampshire; 41-58.

KEYDER, Ç. (2010) "Port Cities in the Belle Epoque", Kolluoğlu B. and Toksöz M. (eds) Cities of Mediterranean from Ottomans to the Present Day, I.B. Tauris, New York.

KEYDER Ç., E.Y. ÖZVEREN, D. QUATAERT (1993) Port Cities in the Ottoman Empire: Some Theoretical and Historical Perspectives, Review XVI; 519-58.

KOSTOF, S. (1992) The City Assembled: Urban Patterns and Meanings Through History, Thames and Hudson, London.

KRIER, R. (1991), Urban Space, fifth edition, Rizzoli, New York.

LLEWELYN-DAVIES (2000), Urban Design Compendium, English Partnerships and The Housing Corporation, London.

MATTSON, K. (1999) Reclaiming and Remaking Public Space: Toward an Architecture for American Democracy, National Civic Review, v:88, n:2; 133-44.

MOUGHTIN, C. (2003) Urban Design: Street and Square, Architectural Press, Oxford.

MUMFORD, L. (1961) The City in History, Harcourt, New York.

MUNOZ, F. (2003) Lock living: Urban Sprawl in Mediterranean Cities, Cities, 20 (6); 381-5.

NORBERG-SCHULZ, C. (1984) Genius Loci: Towards a Phenomenology of Architecture, Rizzoli, New York.

OĞUZ, R. (1924) Guide Commercial D'Adana, Djihan Freres, Istanbul.

RISK, H. (1853), The Thistle and The Cedar of Lebanon, Wertheimer, London. 
ROSSI, A. (1999) The Architecture of the City, MIT Press, Cambridge.

ROWE, P.G. (1997) Civic Realism, MIT Press, Cambridge, London.

SELVİ ÜNLÜ, T. (2007) 19. Yüzyılda Mersin'in Kentsel Gelişimi [Urban Development of Mersin in 19th Century], unpublished MA. Thesis, Mersin University.

SELVI ÜNLÜ, T. AND T. ÜNLÜ (2009); Mersin from Railway Station to the Lighthouse, Mersin Chamber of Commerce and Industry, Mersin Books Series-1, Mersin.

SIFNEOS, E. (2005) "Cosmopolitanism as a Feature of the Greek Commercial Diaspora", History and Anthropolgy, v:16, n:1; 97-111.

SITTE, C. (1889) City Planning According to Artistic Principles, translation in Collins, G. R. (1986) Camillo Sitte: The Birth of Modern City Planning, Rizzoli, New York.

TIBBALDS, F. (2001) Making People-friendly Towns: Improving the Public Eenvironment in Towns and Cities, Taylor and Francis, London and New York.

TOKATLI N., and Y. BOYACI (1999) “The changing morphology of commercial activity in Istanbul", Cities, v:16, n:3.

ÜNLÜ, T. (2006) “Kentsel Mekanda Değişimin Yönetilmesi [Management of Change in the Urban Built Environment]", METU JFA, v:23, n:2; 63-92.

ÜNLÜ, T. and SELVİ ÜNLÜ, T. (2012) Developing Commerce, Changing City: Mersin 1850-1950, Mersin Books Series-2, Mersin Chamber of Commerce and Industry, Mersin.

VANLI, S, (1976) "Mersin Gümrük Meydanı [Mersin Customs Square]", Mimarlık, n: 76/4, 103-13.

VANLI, Ş. (2001) Şevki Vanlı: Düşünceler ve Tasarımlar [Thoughts and Designs], Mimarlar Derneğ, Ankara.

WEBB, M. (1990) The City Square, Whitney Library of Design, an imprint of Watson-Guptill Publications, New York.

WEBBER, P. (2008) “Outside in: The forgotten model of the European Square", Architectural Theory Review, v:13, n:1; 52-68

WHYTE, W. H. (1980) The Social Life of Small Urban Spaces, Project for Public Spaces, New York.

WILEY, D. (2008) “The Urban Square: Remediating Public Space, Stream”, A Graduate Journal of Communication, v:1, n:1; 72-93.

ZUCKER, P. (1959) Town and Square, Columbia University Press, New York. 
Alındı: 01.11.2011; Son Metin: 01.08.2012 Anahtar kelimeler: kamusal mekan; yerin karakteri; Doğu Akdeniz liman kentleri; Mersin; Gümrük Meydanı.

\section{BİR DOĞU AKDENIZ LIMAN KENTINDE KAMUSAL MEKANIN DEĞİŞEN KARAKTERİ: MERSINN GÜMRÜK MEYDANI'NDAN ULU ÇARŞI'YA}

Bir fiziksel olgu olarak "kamusal mekan", en genel anlamıla toplumdaki herkesin kullanımına açık, bireysel etkileşimin en üst düzeyde olduğu açık alanları, parkları, sokakları ve meydanları kapsamaktadır. Bu alanlar içinde özellikle meydanlar, kentsel yaşamın mikro-kozmosu ve eylemlerin özgürce ifade bulduğu alanlardır. Genelde kamusal mekanlar, özelde ise meydanlar günlük etkinliklerin en ilgi çekici biçimde yer alabileceği alanlar olmuştur. Ancak, son dönemde dünyanın birçok bölgesinde ve kentinde toplumların, giderek kamusal mekanlardan uzaklaştıkları, güvenliğin, özel tüketimin, kişisel konforun ve özel yaşamın ön planda tutulduğu yeni alanlara yönelmiştir. Bunun sonucunda kamusal alan ve kamusal mekan, kentin toplumsal yapısı ve ilişkileri içinde giderek önemini kaybetmekte ve niteliksel olarak çökmeye başlamıştır.

Bu çalışmada, Mersin Gümrük Meydanı'ndaki dönüşüm merkeze alınarak, kamusal mekanın niteliksel özelliklerindeki değişim, kentsel gelişme ve sosyal süreçlerle ilişkisi çerçevesinde sorgulanmakta, kent planlama ve kentsel projelerin değişime etkisi irdelenmektedir. Burada amaç, Mersin Gümrük Meydanı örneğinden yola çıkarak Doğu Akdeniz liman kentlerindeki kamusal mekanın dönüşümüne yönelik karakteristik özellikleri ortaya çıkarmaktır.

Çalışmanın temel kabullerinden birisi, kamusal mekanın varlığının onun karakteri ile doğrudan ilişkili olduğu, karakterin ise mekanı yere dönüştüren etmenlerin üç boyutlu örgütlenmesi ile sağlanabildiğidir. Bu örgütlenme, mekanın benzersiz ve biricik bir varlık olarak toplumsal bellekte önemli bir yer edinmesini sağlamaktadır. Dolayısıyla, mekanın karakter kazanması, o mekanın yerel düzeyde çevresindeki diğer fiziksel unsurlarla (binalar, yapı adaları, sokak örüntüsü vb.) tarihsel bir süreçte kurulmuş olan karşılıklı ilişkilere bağlıdır ve mekanı benzersiz hale getiren bu ilişkiler o mekanı evrensel düzeyde de tekil hale getirmektedir.

Bu çerçevede, araştırmanın merkezinde yer alan Gümrük Meydanı'nın karakterindeki dönüşüm, tarihsel bir süreçte Mersin'in kentsel gelişme süreçleri ve Gümrük Meydanı'nın çevresindeki binaların, yapı adalarının ve sokak örüntüsünün dönüşümü ile birlikte alınmış ve temel olarak iki dönemde incelenmiştir. İlki, Mersin'in ondokuzuncu yüzyıl başında bir Doğu Akdeniz liman kenti olarak kuruluşundan itibaren geçen yaklaşık bir yüzyıllık dönem iken ikincisi yirminci yüzyılın ortalarından itibaren gelişen dönemdir. 1960'lı yılların başında yeni limanın kurulması her iki dönemi birbirinden ayırmaktadır ki yeni liman Gümrük Meydanı'nın dönüşümüne de doğrudan etki etmiştir.

Mersin, Türkiye'nin Akdeniz sahilinde ve ülkenin en verimli topraklarının bulunduğu antik dönemlerde Kilikya, günümüzde ise Çukurova olarak adlandırılan bölgede yer almaktadır. Kent, on dokuzuncu yüzyılın başında, diğer bir anlatımla, Osmanlı İmparatorluğu'nun modernleşme reformlarının ve buna bağlı olarak imparatorluğun dönemin sanayileşmiş ve gelişmiş ülkelere eklemlenmesi sürecinin yaşandığı dönemde bir sahil köyü olarak kurulmuştur. Diğer liman kentleri gibi bu dönemde Mersin, merkez ile çevre ülkeleri arasındaki ilişkinin bir ifadesi olarak Çukurova ve daha geniş olarak Anadolu'daki tarımsal ürünlerin sanayileşmiş merkeze aktarıldığı bir düğüm noktası olmuştur. Öte yandan, gelişen uluslararası ilişkiler ve ticaret -özellikle deniz ticareti, bankacılık, ithalat, ihracat ve 
sigortacılık- Mersin'in bölge içinde hızla gelişmesini ve Doğu Akdeniz'de önemli liman kentleri arasında yer almasını sağlamıştır.

Bu dönemde gelişen uluslararası ilişkiler, kentin biçimlenmesine ve kamusal mekan sisteminin oluşmasına etkide bulunmuştur. Yerel düzeyde ise Gümrük Meydanı'nın karakterinin onu çevreleyen yapılarla, özellikle Gümrük Binası ve Gümrük İskelesi ile bağlantılı olduğu görülmektedir. Ayrıca dönemin tanıklarının anlatıları da Gümrük Meydanı'nın kentin toplumsal belleğinde önemli bir yeri olduğunu göstermektedir.

Diğer birçok Akdeniz liman kenti gibi Mersin de yirminci yüzyılda uluslararası ölçekte değişen ticaret ilişkilerinden etkilenmiştir. Daha önceki dönemde göreceli bir özerkliğe sahip liman kentleri, ticaretin odak noktalarından iken ulus devletlerin biçimlendiği yeni dönemde uluslararası ilişkiler ulus devletlerin başkentleri aracılığıyla kurulmaya başlanmıştır. Bunun sonucunda liman kentleri uluslararası düzeyde önem kaybetmeye ve ulusal bir bağlamın parçası olmaya başlamışlardır. Bununla birlikte, gelişen ulaşım teknolojileri de yeni limanların yapılmasına neden olmuş ve birçok kentte kentten bağımsız kendi içinde kapalı liman alanları ortaya çıاkmıştır.

Uluslararası ilişkilerin ön planda olduğu dönemden ulusal kimliğin ve kültürün oluşturulmaya çalışıldığ1 döneme geçişte kamusal mekan sisteminde önemli değişiklikler gerçekleşmiştir. Bu değişim en açık biçimiyle, kentin kurulduğu ve uluslararası ilişkilerin ön planda olduğu dönemde kentin dışa açılan kapısı olarak nitelendirilebilecek Gümrük Meydanı'nın karakterindeki dönüşümde gözlenebilmektedir. Gümrük Meydanı, giderek kent içindeki önemini kaybetmiş ve bir dizi müdahale sonucunda Ulu Çarşı adını almıştır. Mersin'de 1960'1 yılların başında inşa edilen yeni liman da bu sürecin bir ürünü olarak belirmiştir. Limanın yapımıyla birlikte Gümrük Binası ve Gümrük İskelesi'nin yıkımı sonucunda Gümrük Meydanı varlık nedenini kaybetmiştir.

Doğu Akdeniz'de bir liman kentindeki kamusal mekanın dönüşümünü inceleyen bu çalışma göstermiştir ki kuşkusuz, başarılı bir kamusal mekanın oluşturulması için geçmişten günümüze alıp uygulayabileceğimiz hazır formüller bulunmamaktadır. Ancak bu mekanların tasarlanması ve biçimlendirilmesi sürecinin, mekanı benzersiz ve biricik bir hale getiren toplumsal ve mekansal ilişkileri, mekanın varlık nedenlerini ve toplumsal bellekte yer edinmesini sağlayan etmenleri göz önünde bulunduran bütüncül yaklaşımlarla yönlendirilmesi sağlanmalıdır.

TOLGA ÜNLÜ; B.CP, M.CP, PhD,

Received his degrees at Department of City and Regional Planning, METU. Has research about physical development and planning history of Turkish cities, and especially of Mersin and their morphological transformation. His main fields of interest are urban design, design control, urban morphology and planning and urban history. Has been employed at the University of Mersin since 2006. tunlu@mersin.edu.tr, tolgaunlu@gmail.com 
